\title{
LANSKAP LINGUISTIK KOTA MEDAN: KAJIAN ONOMASTIKA, SEMIOTIKA, DAN SPASIAL
}

\section{MEDAN'S LINGUISTIC LANDSCAPE: ONOMASTICAL, SEMIOTIC, AND SPATIAL STUDIES}

\author{
Sahril, Syahifuddin Zuhri Harahap, Agus Bambang Hermanto \\ Balai Bahasa Sumatera Utara, Kemendikbud \\ Pos-el: sahril1965@gmail.com
}

Naskah diterima tanggal 22 Agustus 2019

Naskah direvisi terakhir tanggal 6 Desember 2019

\begin{abstract}
Language is a marker of social change that occurs in society. Prescriptivism, which is more glorifying language that is considered more modern. Linguistic landscape views urban as text. The meaning is, because language is widely used in public spaces in urban areas. Linguistic landscape is the presence of language between space and place. An interdisciplinary study of the presence of various language issues that interact with other languages in the public sphere. This study describes the phenomenon of linguistic landscape in Medan in the categories of onomastics, semiotics and spatial. The method used, namely qualitative research methods. The research threat uses the linguistic landscape theory of the Landry \& Bourhis (1997) model. The research findings are the use of foreign languages that dominate the landscape in Medan City. Indonesian is no longer the sole authority in a region. Found onomastical, semiotic, and spatial aspects in the linguistic landscape in the city of Medan.
\end{abstract}

Keywors: Linguistic landscape, prescriptivism, onomastical-semiotic-spatial

\begin{abstract}
Abstrak
Bahasa merupakan suatu penanda adanya perubahan sosial yang terjadi di masyarakat. Sikap preskriptivisme, yaitu lebih mengagungkan bahasa yang dianggap lebih modern. Lanskap linguistik memandang perkotaan sebagai teks. Maknanya, karena bahasa banyak dipakai di ruang publik wilayah urban. Lanskap linguistik merupakan kehadiran bahasa di antara ruang dan tempat. Bersifat kajian interdisipliner atas kehadiran berbagai isu bahasa yang berinteraksi dengan bahasa lain di dalam ruang publik. Penelitian ini mendeskripsikan fenomena lanskap linguistik di Kota Medan dalam kategori onomastika, semiotika, dan spasial. Metode yang digunakan, yaitu metode penelitian kualitatif. Ancangan penelitian menggunakan teori lanskap linguistik model Landry \& Bourhis (1997). Temuan penelitian adanya penggunaan bahasa asing yang mendominasi lanskap di Kota Medan. Bahasa Indonesia sudah tidak bisa menjadi penguasa tunggal dalam suatu wilayah. Ditemukan adanya aspek onomastika, semiotika, dan spasial pada lanskap linguistik di Kota Medan.
\end{abstract}

Kata-kata kunci: Lanskap linguistik, preskriptivisme, onomastika-semiotikspasial 


\section{PENDAHULUAN}

Di mana pun kita berada saat ini, baik di wilayah pribadi maupun publik, senantiasa terpampang pemakaian suatu bahasa. Bahasa itu dipakai dalam penamaan kedai atau warung, produk-produk di pasar swalayan, gedung, menu, grafiti, bandara, transportasi umum, pusat perbelanjaan, pengumuman, poster iklan, dan papan reklame.

Pemakaian bahasa dalam wilayah publik ini menjadi fokus kajian lanskap linguistik (LL), sebuah disiplin yang relatif masih baru dan merupakan gabungan dari disiplin akademis linguistik terapan, sosiolinguistik, antropologi, sosiologi, psikologi, dan geografi kultural. Istilah lanskap linguistik kali pertama digunakan oleh (Landry \& Bourhis, 1997), yang membatasinya sebagai bahasa untuk tanda jalan umum, papan reklame, nama jalan dan tempat, nama kedai, nama bangunan pemerintah dalam sebuah kelompok daerah, wilayah, atau kota.

Selanjutnya (Shohamy \& Gorter, 2009) memperluas cakupan tentang LL ini ke bahasa dalam lingkungan, kata, dan citra yang dipajang di ruang publik dan menjadi pusat perhatian di suatu wilayah yang pesat pertumbuhannya. Dalam kajian lain, (Dagenais, Moore, Sabatier, Lamarre, \& Armand, 2008) memperkenalkan gagasan LL dengan kata environmental print, yakni perkotaan sebagai teks. Maknanya, bahasa banyak dipakai di ruang publik wilayah urban karena wilayah ini dianggap sebagai teks yang layaknya penuh dengan ingar-bingar pemakaian bahasa.

Fenomena urban di Kota Medan setiap tahunnya terus meningkat. Beberapa faktor terjadinya urban di Kota Medan, di antaranya adalah melanjutkan pendidikan, mencari pekerjaan, membuka usaha baru. Faktor terakhir itulah kiranya yang memarakkan penggunaan bahasa di ruang publik Kota Medan. Ketika membuka usaha, mereka menunjukkan kemampuan bilingual mereka. Hal itu bisa dilihat dari teks yang terpampang di muka ruang usaha mereka yang lebih banyak menampilkan teks berbahasa asing meskipun kadang terlihat kesalahan grammar dan ejaan.

Bahasa asing, khususnya bahasa Inggris, muncul terutama dalam penamaan produk-produk yang dianggap modern. Nama-nama kafe dan tempat-tempat gaul pun cenderung muncul dalam bahasa Inggris. Toko-toko yang menjual barang-barang untuk konsumsi kalangan menengah ke atas lebih dominan menggunakan bahasa Inggris misalnya untuk produk bayi Little Box: Homemade Baby and Kid Meals. Begitu juga untuk produk makanan hewan seperti makanan kucing dan anjing Complete Pet Supplies.

Setiap poster iklan berbagai jenis produk juga mengandung paling tidak satu atau dua frasa dalam bahasa Inggris. Yang menarik, ada semacam tren untuk memberi nama kompleks perumahan baru dengan menggunakan bahasa Inggris.

Fenomena ini seakan ingin menunjukkan bahwa masyarakat Kota Medan "sangat melek akan globalisasi dan modernisasi". Akan tetapi, sebenarnya bahasa Inggris digunakan untuk menaikkan gengsi dari produk yang ditawarkan atau pesan yang disampaikan.

Penggunaan bahasa yang berbeda untuk sebuah tanda juga merefleksikan kekuasaan, status, dan kepentingan ekonomi dari bahasa yang ada di Kota Medan. Dari beberapa penelitian ditemukan bahwa tanda yang berbasis multibahasa cenderung menyematkan bahasa Inggris sebagai salah satu bahasa yang digunakan, tidak hanya terjadi di kota-kota besar dan ibukota provinsi bahkan hingga ke desa-desa (Kusumaningsih, Sudiatmi, \& Muryati, 2013), (Riani, 2014), dan (Wijana, 2014). Penggunaan bahasa Inggris pada ranah bisnis bertujuan untuk meningkatkan penjualan dan memunculkan motivasi ekonomi di kalangan konsumen. Salah astu penyebab menyebarnya bahasa Inggris ialah faktor globalisasi.

Kasus yang sama juga terjadi di Timor-Leste, yakni maraknya penggunaan bahasa Inggris, Portugis, dan Indonesia (Taylor-Leech, 2012). Bahkan, sebuah universitas di Jepang mulai memunculkan 
bahasa Inggris di lingkungan kampus dalam rangka stimulasi internasionalisasi kampus (Wang, 2015).

Beberapa penelitian yang telah dilakukan mengarahkan bahwa alasan ekonomi menjadi faktor kuat penggunaan bahasa asing (terutama bahasa Inggris) daripada bahasa Indonesia atau bahasa daerah (Kusumaningsih et al., 2013), (Riani, 2014), dan (Wijana, 2014).

Hasil penelitian lainnya menunjukkan adanya pengaruh yang kuat antara kebijakan bahasa dan penggunaan bahasa di ranah publik (Cenoz, J., \& Gorter, 2006), (Manan, David, Dumanig, \& Naqeebullah, 2015), (Spolsky, 2004), dan (Taylor-Leech, 2012).

Kajian bahasa pada ranah publik, dengan LL merupakan kajian (sosio)linguistik modern yang melibatkan studi onomastika, semiotik, dan spasial (Akindele, 2011), (Aribowo, 2017), (Nash, 2016), (Wolf, Hans-Georg, Bernhard \& Magdalena, 2012). Kajian ini melibatkan bahasa yang tertuang dalam petunjuk jalan, papan iklan, nama jalan, nama daerah, nama toko, dan petunjuk-petunjuk umum pada bangunan pemerintah (Landry \& Bourhis, 1997).

Meskipun dapat dikatakan sebagai cabang ilmu baru, pengkajian LL secara serempak telah dilakukan di beberapa negara seperti: Malaysia (Manan, David, Dumanig, \& Naqeebullah, 2015), Singapura (Tang, 2016), Brunei Darussalam (Coluzzi, 2012), Timor-Leste (Taylor-Leech, 2012), Kamboja (Kasanga, 2012), Hongkong (Wolf, HansGeorg, Bernhard \& Magdalena, 2012), Jepang (Backhaus, 2006), (Backhaus, 2007), Bostwana (Akindele, 2011), negara-negara Baltik (Kreslins, 2003), Australia Selatan (Koschade, 2016), Taipei (Curtin, 2015), dan Bosnia (Lay, 2015), (Dany Ardhian, 2018), (Erikha, 2018), dan (Lestari, 2013).

Fenomena meningkatnya penggunaan bahasa pada nama jalan, poster, iklan, papan informasi dan imbauan resmi pemerintah telah menjadi topik hangat para akademisi (Koschade, 2016), (Madson, 2016), dan (Tang, 2016). Beberapa negara atau kota juga telah menerbitkan peraturan-peraturan terkait kebijakan bahasa yang digunakan dalam ranah publik. Demikian juga dengan Sumatera Utara yang telah memiliki Peraturan Daerah (Perda) Nomor 8 Tahun 2017, tentang Pengutamaan Bahasa Indonesia, Pelindungan Bahasa Daerah dan Sastra Daerah.

Regulasi terkait LL secara simultan juga mengatur kebijakan bahasa pada ranah pendidikan, media, kehidupan sosial ekonomi, dan sebagainya. Menurut (Spolsky, 2004) memilah antara kebijakan dan praktik yang disebutnya sebagai ideologi, praktik, dan manajemen. Menurut pengamatannya secara aktual, praktik-praktik penggunaan bahasa dapat mengungkap ideologi bahasa masyarakat lokal dalam kaitannya dengan kebijakan bahasa nasional.

\section{LANDASAN TEORI}

Lanskap linguistik mengklaim bahwa tanda yang ada pada lanskap berupa teks ilustratif yang dapat dibaca dan difoto yang dapat dibedah secara linguistis dan kultural (Gorter, 2006), (Shohamy, E., Ben-Rafael, L., \& Barni, 2010), dan (Shohamy, E., \& Gorter, 2009). Tanda yang dimaksud merupakan tanda yang digunakan dalam rangka diseminasi pesan umum kepada publik dalam bentuk informasi, petunjuk, peringatan, dan semacamnya.

Tanda ini juga sering kali muncul pada konteks komersial seperti pemasaran dan iklan yang fungsi utamanya untuk menarik perhatian terhadap sebuah produk atau bisnis (Backhaus, 2007), (Kasanga, 2012), Dumanig, \& Naqeebullah, 2015), dan (Wolf, H.-G., Hans-Georg Wolf Zweitgutachter, H., Bernhard Bielick, H., \& Magdalena, 2012).

Fokus utama LL mengungkap kejelasan (visibility) dan arti penting bahasabahasa tulis yang digunakan pada ranah publik. Secara singkat dikatakan bahwa LL merupakan potret situasi kebahasaan di ranah publik (biasanya melibatkan negara atau kota) tentang pola-pola umum penggunaan bahasa, kebijakan bahasa, sikap bahasa, dan konsekuensi kontak bahasa yang terjalin dalam waktu jangka panjang. 
Lanskap linguistik merupakan kehadiran bahasa di antara ruang dan tempat. Menurut (Puzey, 2016) LL menggambarkan sebagai kajian interdisipliner atas kehadiran berbagai isu bahasa yang berinteraksi dengan bahasa lain di dalam ruang publik. Meskipun LL merupakan istilah yang relatif baru dalam kajian linguistik terapan, konsep ini telah bersinggungan dengan konsep lain, seperti sosiolinguistik, multilingualisme, kebijakan bahasa, geografi budaya, semiotik, sastra, pendidikan, dan psikologi sosial.

Melalui interaksi bahasa di ruang publik, kita dapat menelusuri konstruksi simbolis sebuah ruang dan penggunaan bahasa dalam memediasi relasi sosial dan politik. Ini diperkuat dengan pernyataan (Ben-Rafael, Eliezer, Shohamy, Amara, 2006) bahwa LL mengacu pada objek linguistik yang menandai ruang publik.

Sementara itu, menurut (Landry \& Bourhis, 1997) mengemukakan bahwa LL memiliki dua fungsi: fungsi informasional dan fungsi simbolis. Pada fungsi informasional, makna penanda membedakan wilayah geografis penduduk yang memberikan bahasa pada nama tempat itu. Dengan kata lain, bahasa berfungsi sebagai penanda wilayah masyarakat penuturnya dan pembeda dari wilayah penduduk lain yang berbeda bahasanya.

Pada fungsi simbolis, kehadiran atau ketidakhadiran bahasa sebuah kelompok pada papan jalan-misalnya berdampak pada perasaan sebagai bagian kelompok itu. Fungsi simbolis juga erat kaitannya dengan keterwakilan identitas sebuah etnis. Menurut (Lou, 2016) dan (Blommaert, 2013) ruang sebagai arena interaksi sosial manusia dan melakukan serangkaian kegiatan budaya.

Ruang interaksi itu dapat dinilai sebagai bentuk aksi/tindak tanduk bahwa ruang sebagai sesuatu yang kompleks dan berisi berlapis-lapis aktivitas di dalamnya. Dengan demikian, bukti yang ditampilkan dalam kajian LL ini menjadi pola komunikasi manusia yang diwakilkan melalui bahasa tulis.

Kajian onomastika (ihwal nama dan penamaan) (Kusik, 2018), khususnya toponomastik (nama tempat), menjadi bidang yang tak terlepaskan dari LL. Nama atau papan nama yang ada di jalanan, yang notabene bagian dari lanskap, dianggap bentuk interaksi antara bahasa, ruang, dan tempat.

Kerangka konsep LL dan fokusnya pada nama tempat, juga berkaitan erat dengan keadaan vis a vis antara bahasa minoritas dan mayoritas serta pemberlakukan upaya politik terhadap bahasa lokal dalam rangka pengubahan nama tempat serta bagaimana sikap masyarakat terhadap isu itu (Kostanski, 2009).

Singkat kata, terdapat hubungan antara LL, nama-nama dan kebijakan bahasa yang tertuang dalam sejumlah isu seperti dinamika pemajangan papan nama dengan bahasa ganda (atau lebih), konflik yang dipicu, penamaan ulang, hingga bahasa sebagai identitas sebuah kelompok (Puzey, 2016).

Berbagai tanda di ruang publik merefleksikan dan mengatur tatanan ruang tempat ia beroperasi. Fitur sosiologis, kultural, sosiolinguistis, dan politis dari ruang akan menentukan bagaimana tanda terlihat dan bekerja, dan tanda juga akan berperan dalam organisasi dan regulasi keruangan dengan menetapkan siapa saja penerima tanda itu.

Tanda di ruang publik juga dapat memaksa audiensi agar mengikuti aturan mainnya, dengan sejumlah batasan dan pedoman norma yang dianut bersama (Blommaert, 2013). Tanda dalam ruang publik tentunya dibuat bukan tanpa alasan. Tanda memiliki pesan dan tidak pernah netral, memiliki keterhubungan dengan struktur sosial, hierarki, dan kekuasaan (Stroud \& Mpendukana, 2009). Alasannya, ruang publik merupakan area sekaligus juga instrumen pengaturan dan pengendalian kekuasaan.

Menurut (Blommaert, 2013:40) bagaimana ruang mengatur rezim semiotik bahasa? ("how does space organize semiotic regimes of language?") Tentu saja semua tanda yang diungkapkan melalui papan jalan menjalankan praktik wacana dengan atribusi kepada sebuah ideologi (Blackwood \& Tufi., 
2015). Menurut (Blommaert, 2013) menyebutkan komunikasi di ruang publik tidak lepas dari komunikasi pada ranah kuasa dan bersifat sosiolinguistis.

Berbicara tentang tanda tentu tak lepas dari isu semiotis. Bahasa di ruang publik yang berada di jalanan (lanskap) merupakan penanda sebuah ruang. Sebuah teori klasik milik (Richards, 1923) telah menyinggung bagaimana sebuah konsep (referensi) yang mewakili objek (referen) diwakilkan oleh lambang (simbol bahasa). lanskap berkaitan dengan peran bahasa di ruang publik, misalnya Jalan Jenderal Sudirman (di Jakarta) sebagai toponimi merupakan lambang bahasa atas objek jalan yang membentang dari Bundaran Hotel Indonesia hingga penanda Patung Pemuda Membangun (dikenal juga dengan Patung Bundaran Senayan). Bagi masyarakat Jakarta, jalan itu memiliki konsep yang sangat bervariasi di dalam benak mereka. Baik itu sebagai konsep jalan ibu kota, jalanan yang padat, maupun sebagai jalan dengan banyak gedung pencakar langit.

Konsep tersebut memperlihatkan bagaimana semiotik berperan dalam LL serta mencoba menangkap bahasa sebagai perantara antara ruang dan tempat. Eksistensi bahasa di ruang publik dapat ditelaah menggunakan perspektif analisis wacana yang kemudian disebut konsep geosemiotik. Geosemiotik merupakan kajian pemaknaan sosial atas penempatan material tanda-tanda, muatan wacananya, serta sikap kita terhadap dunia material itu. Konsep itu berawal dari pewacanaan terdahulu atas kehadiran ruang fisik sebagai latar semata, tetapi saat ini telah dievaluasi kembali sehingga menjadi bagian dari teks itu sendiri (Scollon, \& Scollon, 2003).

Kajian LL pada dasarnya bersifat sosio-ekonomis, dalam arti bahwa ia mencari korelasi antara pemakaian bahasa tertentu di sebagian wilayah perkotaan dan standar hidup di wilayah itu pada umumnya. Sudah umum disepakati bahwa pemakaian bahasa dalam LL terangkum ke dalam dua kategori, (top-down) dan pemakaian bahasa secara bawah-atas (bottom-up).

Kategori atas-bawah mencakupi pemakaian bahasa di ruang publik yang dibuat oleh badan atau lembaga pemerintah, lembaga publik yang mengurusi persoalan agama, pemerintahan, kesehatan, pendidikan dan kebudayaan, misalnya: papan tanda nama jalan, dan maklumat umum; sedangkan kategori bawah-atas meliputi pemakaian bahasa oleh pemilik kedai/toko (pakaian, makanan, perhiasan), kantor/pabrik/agen swasta, maklumat pribadi (sewa/jual mobil/rumah) termasuk iklan lowongan kerja.

Rentang diagonal dari kategori pertama hingga kategori kedua itu menunjukkan derajat seberapa resmi dan tak resmi dipakaianya sebuah bahasa, sebagaimana dinyatakan oleh (Ben-Rafael, Eliezer, Shohamy, and Amara, 2006).

Sesuai namanya, LL sungguh sosiosimbolis dan merupakan panorama bahasa yang dibentangkan untuk dilihat, baik di jalan, sudut jalan, taman, maupun gedung. Semua itu merupakan tempat berlangsungnya kehidupan publik masyarakat. Sifat yang demikian itu, menjadi simbol masyarakat, komunitas, dan wilayah. Bagi (Ben-Rafael, Eliezer, Shohamy, and Amara, 2006), LL dianggap penting karena ia tidak menggambarkan latar belakang dan potret kehidupan sehari-hari kita semata, juga merupakan sumber pembelajaran bahasa yang bernilai. LL juga membentuk cara kita berinteraksi sebagai anggota masyarakat dan memberi kita identitas. Dan yang utama, ia berada di manapun dan terbuka serta bebas biaya bagi siapa pun.

$$
\text { yakni pemakaian bahasa secara atas-bawah Denah 1: Fungsi Lanskap Linguistik }
$$




\section{METODE PENELITIAN}

Kajian LL menggunakan metode penelitian kualitatif yang ditempuh dengan jalan melakukan dokumentasi objek LL. Secara metodologis, analisis LL mengandalkan fotografi dan analisis visual. Pengumpulan data berfokus pada keterlibatan fotografi yang tervisualisasi dari teks yang berada pada tanda-tanda di ruang publik. Ruang lingkupnya termasuk tempat-tempat yang secara geografis merupakan lokasi strategis.

Analisis LL mengikuti ancangan (Landry \& Bourhis, 1997). Ancangan ini terbagi menjadi enam tataran: (1) analisis mikrolinguistik, (2) analisis tipe kode bahasa, (3) analisis perilaku bahasa, (4) analisis psikologikal, (5) analisis sosio-psikologikal, (6) Analisis sosiologikal. Dengan analisis yang bertahap itu, aspek-aspek yang ada di dalam LL akan terungkap sesuai dengan fungsi LL pada fungsi informasi dan fungsi simbolik.

Analisis mikrolinguistik bertumpu pada penggunaan satuan lingual frasa-klausa pada teks-teks LL, bagaimana teks tertulis dalam bentuk frasa, klausa, frasa+klausa, Klausa+frasa, Klausa+klausa. Di dalamnya juga dibahas penggunaan kode bahasa, monolingual, bilingual, dan bahasa apa yang digunakan. Analisis pada tataran ini melihat bagaimana perilaku bahasa yang digunakan.

Analisis selanjutnya adalah analisis psikologikal. Pada analisis ini tertuang dua hal: pemahaman atas makna teks (baik makna leksikal maupun makna kultural) dan sikap terhadap teks (bagaimana kondisi psikologi ketika teks dibuat dan dibaca, apakah senang, bahagia, sedih, kecewa, dan marah). Analisis ini melibatkan relasi sosial dalam komponen analisisnya, seperti etnis, status sosial, agama, dan gender.

Selesai pada tataran analisis psikologikal, tataran berikutnya adalah tataran sosio-psikologikal. Tataran ini menganalisis frekuensi individu atas interaksinya dengan teks, seperti pengalaman pribadi, interaksi dengan media, interaksi yang dibangun dalam pendidikan, dan interaksi secara langsung dengan LL. Analisis ini bertujuan untuk memberikan gambaran bagaimana seorang individu membagikan pemahaman dan pengalamannya kepada masyarakat dan dapat membentuk konstruksi sosial. Secara jelasnya, analisis ini mengomunikasikan persepsinya kepada orang lain atas pengalaman dan pemahamannya berinteraksi dengan teks.

Tahap berikutnya adalah analisis sosiologikal. Komponen analisisnya bertumpu pada vitalitas etnolinguistik. Vitalitas etnolinguistik melihat bagaimana masyarakat dibekali oleh kekuatan politik, kekuatan ekonomi, dan kekuatan demografi. Analisis ini menuju pada analisis kekuatan sosial. Jika suatu teks ini diproduksi oleh kekuatan ekonomi, politik, dan jumlah penduduk, apakah nanti akan berpengaruh terhadap simbol-simbol yang ditampakkan pada masyarakat. Jadi, keseluruhan tataran tersebut melibatkan banyak aspek, yaitu aspek bahasa, aspek psikologi, aspek sosiopsikologi, dan aspek sosiologi. Hal itu yang menyebabkan bahwa kajian LL merupakan kajian antardisipliner.

Semua foto yang diambil pada ruang publik di Kota Medan ini akan dianalisis menggunakan dua fungsi sebagai objek LL, seperti yang dijelaskan oleh (Landry \& Bourhis, 1997): fungsi informasional dengan mengkaji dari aspek kebahasaannya; sedangkan fungsi simbolis yang melihat bahasa dan interaksinya. Fungsi simbolis data menggali pesan dasar dari fakta LL dan hierarki suatu bahasa atas bahasa lain dan menjelaskan juga bagaimana sebuah lanskap dibangun.

Kajian terhadap lanskap linguistik ini juga akan dilihat dari fenomena preskriptivisme. Dalam sosiolinguistik, preskriptivisme (bahasa Latin: $\quad$ praescribere-mempreskripsikan; memerintahkan; normativisme adalah istilah yang merujuk kepada praktik menyusun norma dan pedoman penggunaan bahasa alami dengan maksud memengaruhi penuturnya agar berpegang pada pola yang diusulkan. Kaidah tersebut bisa mengatur berbagai-bagai aspek bahasa seperti pelafalan, infleksi, semantik, sintaksis, dan 
fraseologi, serta unsur ekstralinguistik seperti sistem ejaan. Kecenderungan preskriptivis bisa menimbulkan penggolongan bentuk bahasa yang tidak diakui sebagai "inferior", "keliru" ataupun "tidak logis"; tendensi tersebut juga berkaitan dengan konsep salahbenarnya bahasa (Heyd, 2014).

Beberapa peneliti mengartikan "preskriptivisme" sebagai konsep mempromosikan suatu ragam bahasa sebagai varietas yang lebih utama kedudukannya, sehingga menganggap ideologi bahasa standar sebagai elemen konstitutif preskriptivisme atau bahkan menyamakan preskriptivisme dengan sistem pandangan itu (Mooney, 2018).

Istilah "preskriptivisme" merujuk kepada segala bentuk kegiatan yang bertujuan mengusulkan atau mendorong suatu cara penggunaan bahasa, tanpa menyiratkan bahwa praktik-praktik tersebut selalu terkait dengan penyebaran ideologi bahasa standar. Selain dua hal tersebut ada juga pengertian bahwa sikap preskriptif adalah pendekatan kodifikasi bahasa yang mementingkan pendapat si penyelidik, berbeda dengan bentuk-bentuk kodifikasi yang mendasarkan kegiatannya pada fenomena penggunaan bahasa yang sebenarnya, walaupun begitu, pendekatan kedua tersebut pun bisa dikatakan mengandung sifat preskriptif.

\section{PEMBAHASAN}

Analisis data fenomena inovasi dan perubahan linguistik, pada ruang publik Kota Medan dalam konteks lanskap linguistik secara kritis memeriksa bagaimana onomastika, semiotik, dan spasial untuk preskripivisme masyarakat.

Fenomena masyarakat pascaindustri, gagasan ideologi bahasa, khususnya yang berkaitan dengan normativisme dan preskriptivisme populer, telah dibanjiri dengan bahasa Inggris. Preskripivisme dipengaruhi oleh faktor sosioteknik di internet, seperti kebangkitan komersialisme dan iklan publik ke dalam teks ruang publik yang diproduksi oleh semua tingkat kelas sosial.
Mekanisme kekuatan linguistik yang berbeda semakin dibingkai sebagai kekuatan dari bawah ke atas. Pengawasan bahasa tidak lagi terbatas pada kekuatan institusional. Kehadiran regulasi pun tidak lagi berfungsi sebagai pengawas penggunaan bahasa di ruang publik. Apalagi regulasi itu tidak ada berupa sanksi yang tegas. Merujuk di Sumatera Utara, sebenarnya ada Peraturan Daerah tentang penggunaan bahasa Indonesia di ruang publik. Di perda ini pun ada sanksi, akan tetapi eksekusi di lapangan yang belum berjalan.

Kota Medan sebagai salah satu kota metropolitan di tanah air, mengalami serbuan penggunaan bahasa yang begitu dahsyat, khususnya bahasa Inggris. Nyaris di semua lini ditemui penggunaan bahasa Inggris. Bahkan, institusi pemerintah sendiri pun, ikut-ikutan menggunakan bahasa Inggris. Lihat gambar 1.

Lanskap linguistik Kota Medan mengindikasikan bagaimana sikap bahasa masyarakat terhadap bahasa-bahasa yang dikuasainya. Meskipun pada faktanya bahasabahasa asing banyak digunakan di ranah publik, tetapi bahasa tersebut bukan menjadi bahasa yang dikuasai atau dituturkan pada percakapan setiap hari. Bahasa-bahasa asing yang mendominasi lanskap di Kota Medan merupakan bahasa-bahasa yang dipandang memiliki nilai dan kekuatan ekonomi yang lebih apabila dibandingkan dengan bahasa Indonesia dan bahasa daerah.

Pada kasus ini bahkan pemerintah sendiri, justru terjebak juga mengikuti arus penggunaan bahasa asing, seperti pada foto berikut ini. Salah satu institusi pemerintah lebih memilih "call center" daripada "narahubung", begitu juga pada salah satu lembaga pendidikan tinggi, memilih nama institusinya "Digital Library" daripada "perpustakaan digital". Ironis sekali, seharusnya dua lembaga ini sebagai panutan dalam hal penggunaan bahasa Indonesia, tetapi justru bahasa asing. 

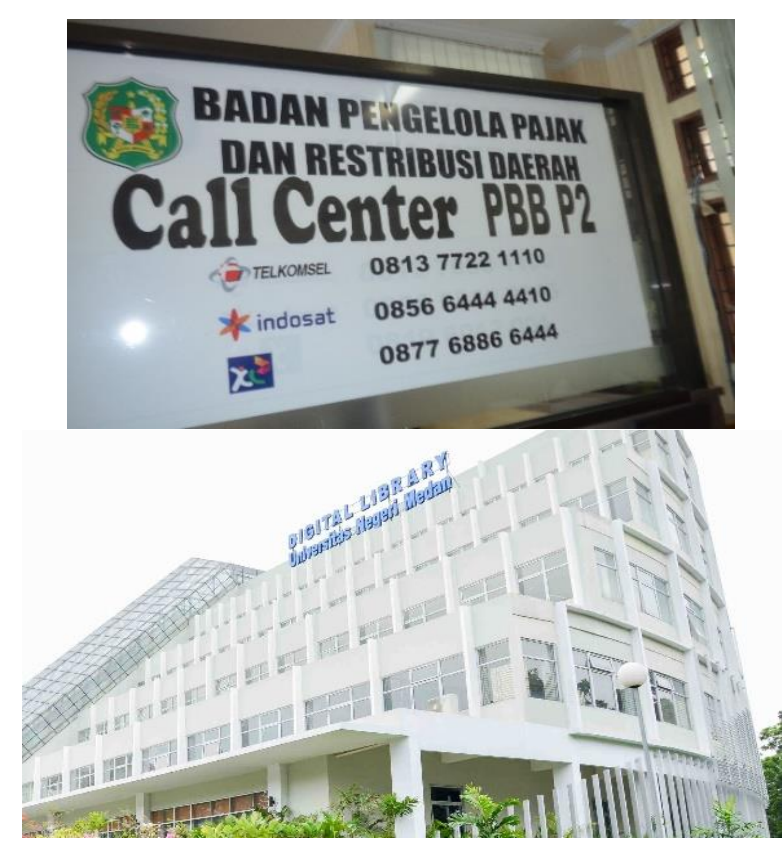

Gambar 1

Penggunaan LL pada instansi resmi

Perhatikan, bagaimana bahasa-bahasa yang dipilih untuk mengisi teks-teks tersebut. Ada bahasa Indonesia dan bahasa Inggris. Informasi terkait perilaku sosiolinguistik dan perbandingan penggunaan bahasa pada tataran ruang resmi. Seharusnya pada tataran resmi, teks-teks diproduksi oleh pemerintah haruslah mengutamakan penggunaan bahasa Indonesia. Seperti pada foto berikut yang tertib menggunakan bahasa Indonesia.

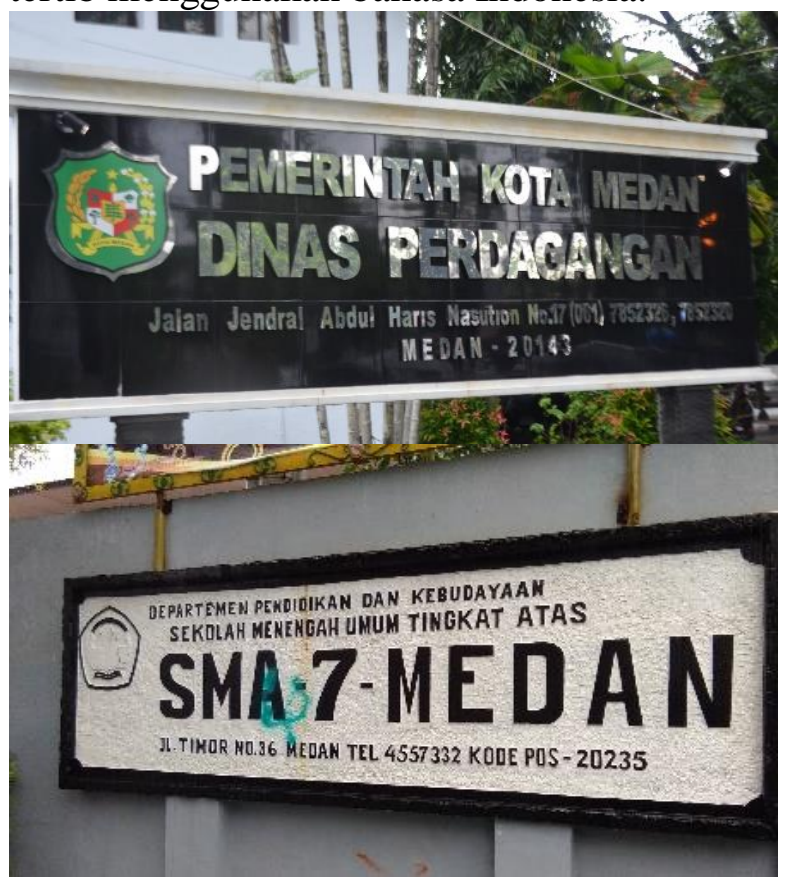

Gambar 2

Penggunaan $L L$ pada instansi pemerintah
Pentingnya kedudukan bahasa Indonesia dalam kehidupan sehari-hari. Bahasa Indonesia merupakan identitas bangsa yang harus dijaga dan dilestarikan. Pentingnya menjaga integritas bahasa Indonesia bertujuan untuk mereduksi pengaruh budaya asing terutama pengaruh bahasa asing yang telah masuk menguasai ruang atau domain penggunaan bahasa Indonesia dalam masyarakat (Warung, 2009).

Diketahui bahwa teks-teks tersebut hadir dan didistribusikan dalam populasi dan komunitas masyarakat yang ikut serta di ruang tersebut sehingga ada investigasi terkait relasi kuasa dalam suatu wilayah, sebagaimana yang disampaikan oleh Blommaert dan Maly dalam (Lou, 2016). Imbauan di ruang publik merupakan suatu ajakan, imbauan, dan peringatan pada masyarakat untuk melaksanakan apa yang dikehendaki oleh pembuat imbauan (penguasa). Dengan demikian, bahasa merupakan unsur penting dalam penerapan kekuasaan (Wahyuni, 2016).

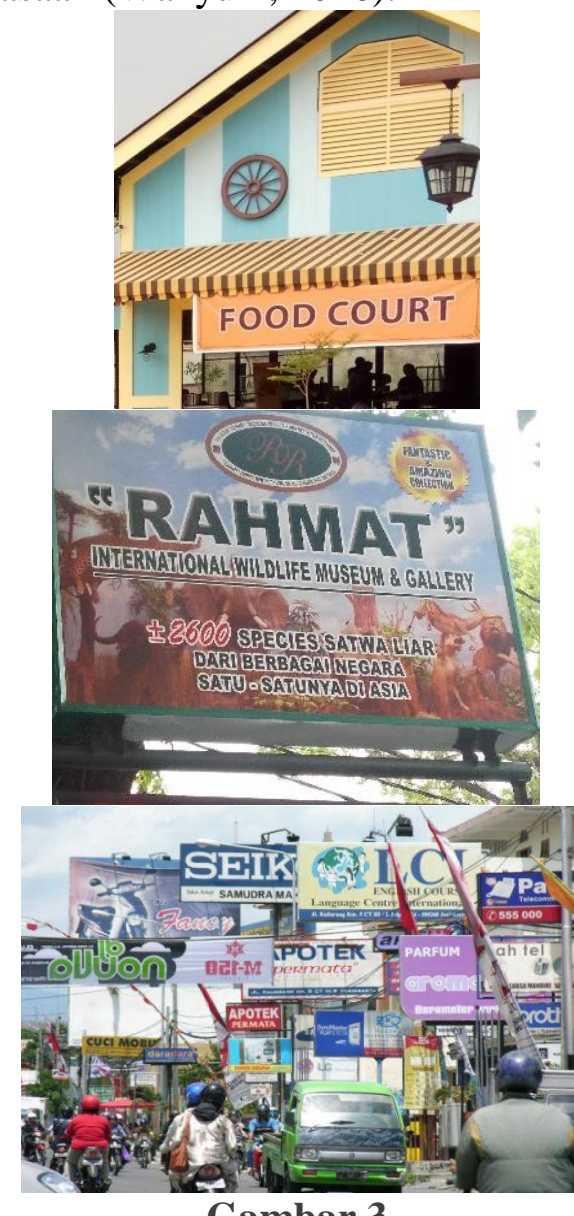

Gambar 3 
Penggunaan LL oleh instansi swasta

Mayoritas menggunakan teks bahasa Inggris. Teks tersebut juga digunakan dalam aktivitas-aktivitas tertentu, seperti aktivitas ekonomi, pendidikan, politik, budaya, dan agama. Dengan pilihan kode bahasa tertentu, teks-teks tersebut ada yang mendominasi. Secara spasial, sebaran LL Kota Medan ini berada pada lokasi strategis. Nyaris semua sebaran LL Kota Medan mencari posisi yang berada pada inti kota sehingga terkadang membuat kesemberautan tata keindahan kota. Karena itu, unsur semiotikanya pun hilang.

Bahasa yang digunakan merupakan bahasa yang singkat dan pendek. Umumnya tidak mengindahkan unsur sintaksis dan morfologi. Hal itu mungkin bertujuan untuk memudahkan masyarakat dalam mengingat. Ragam bahasa yang digunakan dalam penulisan adalah ragam bahasa usaha. Ragam bahasa ini berada di antara ragam formal dan ragam informal. Kita sadari bahwa, aspek terpenting dari sebuah usaha/bisnis adalah membuat penjualan, baik produk ataupun jasa. Jika tidak ada penjualan, tidak ada bisnis yang akan bertahan lama. Dan setiap penjualan selalu diawali oleh promosi atau iklan. Sehingga aspek yang berkaitan dengan penggunaan bahasa selalu dinomorduakan.

Bahasa memainkan peranan penting dalam teks-teks di ruang-ruang publik tersebut. Penggunaan bahasa tidak terlepas dari gejala sosial masyarakat. Masyarakat yang terlibat dalam relasi-relasi dan aktivitasaktivitas sosial menggunakan bahasa sebagai alat untuk mengidentifikasi keberadaan anggota masyarakat.

Bahasa merupakan suatu penanda adanya perubahan sosial yang terjadi di masyarakat. Sikap menonjolkan perilaku bahasa tertentu merupakan penanda hadirnya sikap preskriptivisme, yaitu lebih mengagungkan bahasa yang dianggap lebih modern. Hal ini ditengarai karena adanya dominasi kelompok sosial tertentu dalam aktivitasnya, baik aktivitas sosial, politik, ekonomi, pendidikan, dan agama.

Melihat kondisi seperti pada foto di atas, bahasa Indonesia sudah tidak bisa menjadi penguasa tunggal dalam suatu wilayah. Bahasa selalu mengalami kompetisi. Bahasa selalu berjuang memperebutkan penutur. Ada bahasa yang kuat karena faktor kekuatan demografi, ekonomi, kebijakan bahasa, dan ada bahasa yang lemah. Di sini dapat diketahui perilaku masyarakat, apa ideologi bahasa yang dimainkan, bahasa apa yang memiliki power dan prestise, dan bahasa apa yang termarjinalkan, seperti yang dipaparkan oleh (Cenoz, J., \& Gorter, 2006), (Dagenais et al., 2008). Jadi, bahasa memiliki peran dalam merepresentasikan suatu ideologi tentang bagaimana suatu bahasa memiliki kuasa dan prestise atas bahasa lain.

Di samping itu, dominasi media sosial melalui internet juga seakan sebagai pusat gravitasi yang sangat mempengaruhi kondisi langskap linguistik. Dapat disimpulkan bahwa budaya partisipatif dari media digital/sosial, telah memberikan kontribusi besar terhadap perkembangan langskap linguistik.

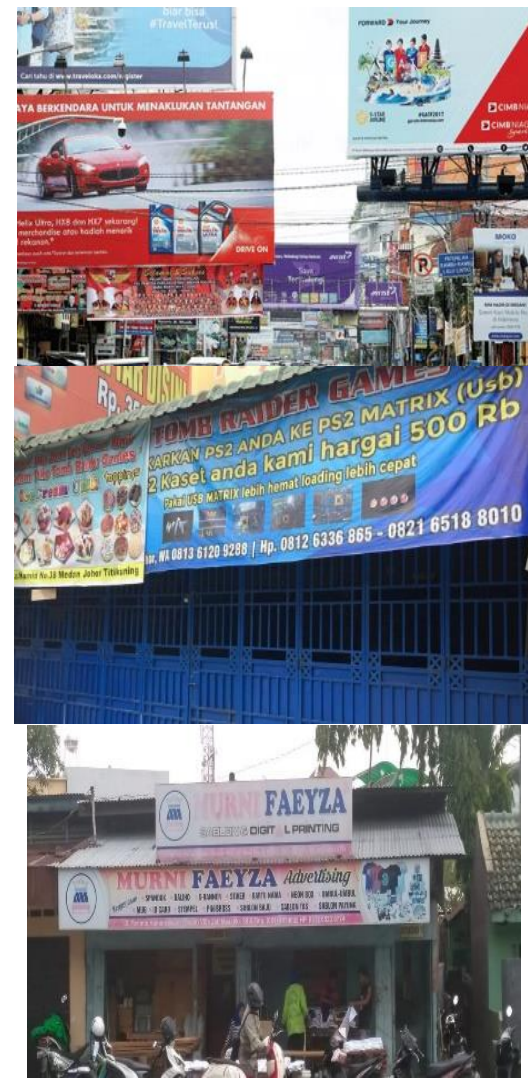

Gambar 4

Penggunaan LL bersifat pengumuman

Ada dua aktor yang perlu dipertimbangkan dalam kajian LL, yaitu produsen teks dan konsumen teks tersebut. Kedua aktor ini saling memengaruhi hasil 
teks di ruang publik. Produsen teks tidak hanya mempertimbangkan produksi teksnya, tetapi siapa yang menikmati produk teks itu. Di sinilah munculnya konsep onomastika, semiotika, dan spasial itu.

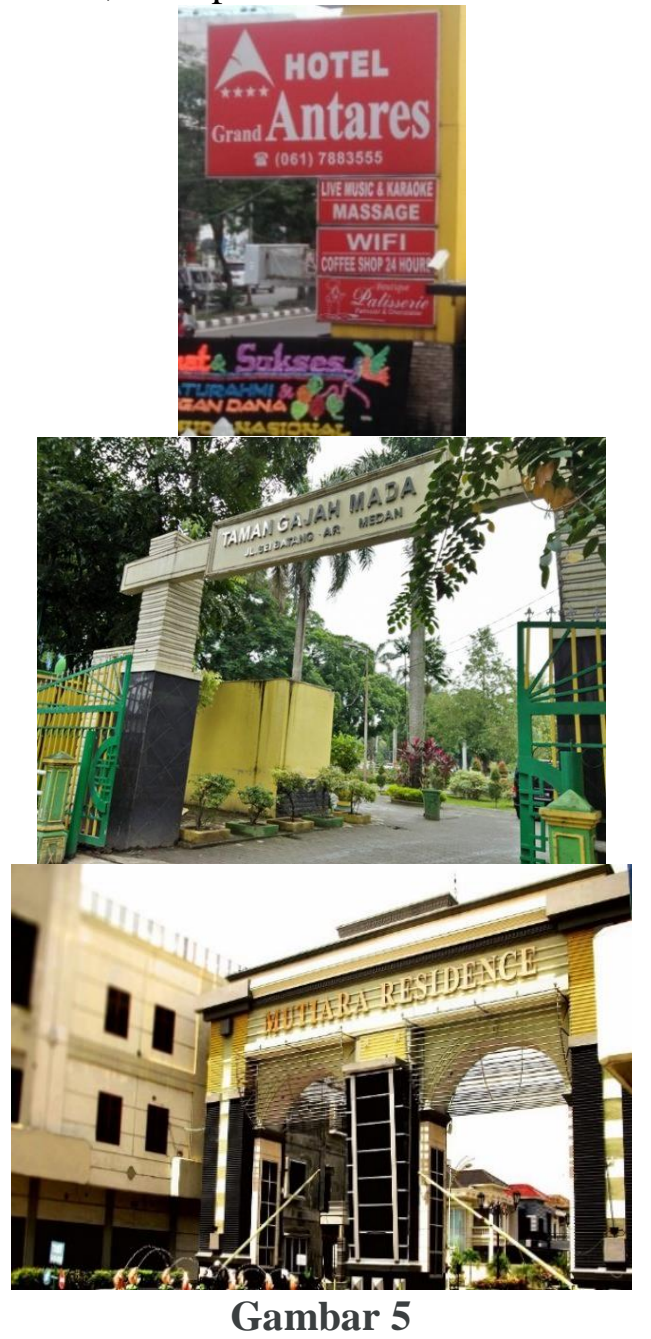

Penggunaan LL pada onomastika

Teks-teks di atas berfungsi untuk menandai kuasa bahasa atas suatu wilayah. Teks yang diproduksi oleh swasta/individu bersifat lebih beragam daripada teks yang diproduksi oleh pemerintah. Hal itu disebabkan kurangnya aturan yang mengatur pola teks-teks tersebut. Fungsi informasi ini merujuk pada informasi yang diberikan kepada pembaca atas nama tempat, informasi umum, nama barang dan jasa.

Fungsi berikutnya, fungsi simbolik. Fungsi ini menandai simbol-simbol apa yang dihasilkan dari kemunculan perilaku teks-teks tersebut. Di sinilah terjadinya ada relasi budaya, identitas kelompok (etnik, gender, status sosial), relasi kuasa (ekonomi, politik, demografi), dan status bahasa (bahasa resmi dan tidak resmi), sejalan dengan enam konsep yang disampaikan oleh (Landry \& Bourhis, 1997).

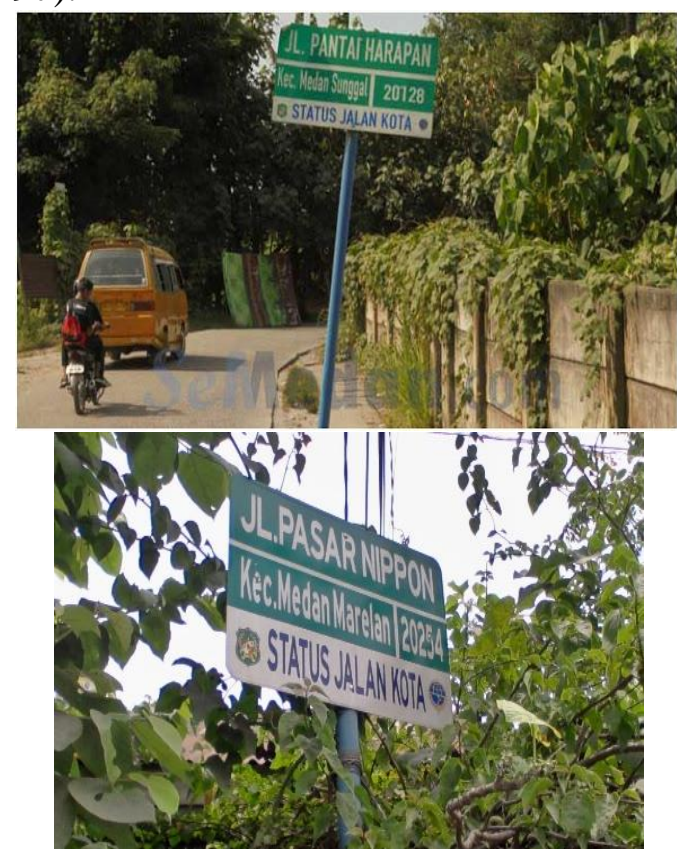

Gambar 6

Penggunaan LL pada Plang Jalan

Nama pada papan jalan sebagai proposisi budaya dapat dianalisis berdasarkan konteks semantik dan konteks pragmatik. Menurut (Rahyono, 2015): analisis lingual dan analisis nonlingual. Pada aspek semantis, Jalan diartikan sebagai 'tempat seseorang atau sebuah objek untuk melintas dari satu tujuan ke tujuan tertentu' (Pusat Bahasa Kemdikbud, 2016). Papan jalan juga memiliki fungsi simbolis (Landry \& Bourhis, 1997).

Berdasarkan penggunaan ejaan ditemukan kesalahan, yaitu 'jl.', seharusnya 'jln.', dan sebaiknya ditulis lengkap jadi ‘jalan'. Berkaitan dengan onomastika, kedua foto di atas menunjukan suatu tempat yang memiliki nilai sejarah. Sementara, dari segi semiotikanya memperlihatkan pesan simbolik akan lokasi yang dituju, sehingga secara spasial menginformasikan kepada masyarakat. Plang nama jalan ini merupakan fakta linguistik, tidak semata-mata sebuah tanda identifikasi tempat. Lebih daripada itu, plang jalan memuat wacana yang diciptakan oleh Pemerintah Kota Medan pada ruang sosialnya.

Perlu diketahui bahwa hakikat kajian LL, memosikan bahasa sebagai perantara 
antara tempat dan ruang. Tidak hanya itu, plang jalan juga sebagai bagian dari kebudayaan dan historisitas yang digunakan sebagai komoditas ekonomi yang dapat menarik wisatawan untuk mengunjungi tempat itu.
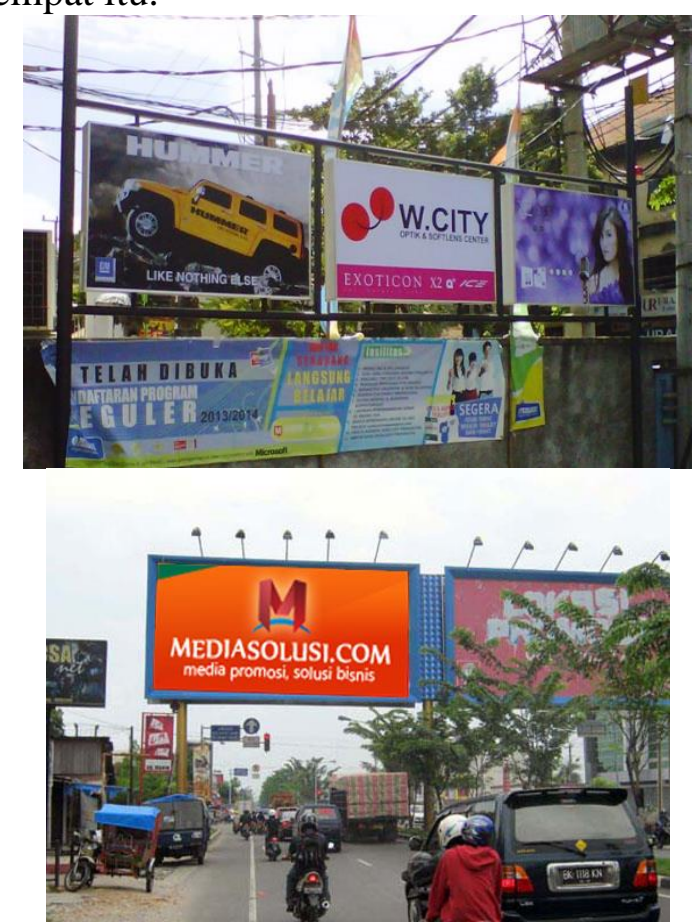

Gambar 7

Penggunaan LL Pada Promisi Produk

Bangsa Indonesia sudah memiliki bahasa sendiri yaitu bahasa Indonesia, tetapi faktanya peran bahasa Indonesia yang seharusnya menjadi tuan rumah di negaranya sendiri, kini mulai tergeser, bahkan tergusur

\section{DAFTAR PUSTAKA}

Akindele, D. O. (2011). Linguistic Landscapes as Public Communication: A Study of Public Signage in Gaborone Botswana. International Journal of Linguistics, $3(1)$, $1-11$. https://doi.org/International Journal of Linguistics

Aribowo, E. K. (2017). Linking Arabic, Islam, and Economy: Onomastics on Bussiness Name of People of Arab Descent in Indonesia. KARSA: Journal of Social and Islamic Culture, 25(2), 284-306. https://doi.org/10.19105/karsa.v25i2. dengan maraknya penggunaan bahasa asing. Era globalisasi yang menawarkan isu perdagangan bebas telah memberikan dampak yang kurang menguntungkan terhadap perjalanan bahasa Indonesia. Bahasa Indonesia seakan-akan menjadi subordinasi bahasa asing (terutama bahasa Inggris) yang peranannya begitu penting dalam komunikasi di bidang iptek dan ekonomi.

\section{PENUTUP}

Berdasarkan tampilan foto yang dianalisis, bahasa Indonesia sudah tidak bisa menjadi penguasa tunggal pada lanskap linguistik di Kota Medan. Terjadi kompetisi antara bahasa Indonesia dengan bahasa Inggris. Dampak kekuatan ekonomi, membuat posisi bahasa Indonesia termarjinalkan. Teks yang diproduksi oleh swasta/individu bersifat lebih beragam daripada teks yang diproduksi oleh pemerintah.

Pengawasan penggunaan bahasa tidak lagi terbatas pada kekuatan institusional, tetapi justru peran arus bawah (bottom up) yang memegang kendali pada kasus lanskap linguistik di Kota Medan. Ada dua aktor yang berperan dalam kajian LL, yaitu produsen teks dan konsumen teks tersebut. Kedua aktor ini saling memengaruhi hasil teks di ruang publik.

\section{0}

Backhaus, P. (2006). Multilingualism in Tokyo: A Look into the Linguistic Landscape. International Journal of Multilingualism, 3(1), 52-66. https://doi.org/10.1080/14790710608 668385

Backhaus, P. (Ed.) (2007). Linguistic Landscapes: A Comparative Study of Urban Multilingualism in Tokyo (Vol. 136). Clevedon: Multilingual Matters. Ben-Rafael, Eliezer, Elana Shohamy, Muhammad Hasan Amara, dan N. T.H. (2006). Linguistic Landscape as Symbolic Construction of the Public Space: The Case of Israel. International Journal of 
Multilingualism, 3(1), 7-30.

Blackwood, R. J. and, \& Tufi., S. (2015).

The Linguistic Landscape of the

Mediterranean: French and Italian

Coastal Cities. London: Palgrave Macmillan.

Blommaert, J. (2013). Complexity, Accent, and Conviviality: Concluding Comments. Applied Linguistics, 34(5), 613-622.

https://doi.org/10.1093/applin/amt028

Blommaert, Jan. (2013). Ethnography, Superdiversity and Linguistic Landscapes: Chronicles of Complexity. Ontario: Multilingual Matters.

Cenoz, J., \& Gorter, D. (2006). Linguistic Landscape and Minority Languages. International Journal of Multilingualism, 3(1), 67-80. https://doi.org/10.1080/14790710608 668386

Coluzzi, P. (2012). The Linguistic Landscape of Brunei Darussalam: Minority Languages and the Threshold of Literacy. Southeast Asia: A Multidisciplinary Journal, 12(1), 112.

Curtin, M. L. (2015). Creativity in polyscriptal typographies in the linguistic landscape of Taipei. Social Semiotics, 25(2), 236-243. https://doi.org/10.1080/10350330.201 5.1010315

Dagenais, D., Moore, D., Sabatier, C., Lamarre, P., \& Armand, F. (2008). Linguistic landscape and language awareness. In Linguistic Landscape: Expanding the Scenery, (pp. 293-309). https://doi.org/10.4324/97802039309 60

Dany Ardhian, S. (2018). Mengenal Kajian Lanskap Linguistik dan Upaya Penataannya dalam Ruang-ruang Publik di Indonesia. Akrab Juara, 3(3), 170-181.

Erikha, F. (2018). Konsep Lanskap Linguistik Pada Papan Nama Jalan Kerajaan (Râjamârga): Studi Kasus di Kota Yogyakarta. Paradigma, Jurnal
Kajian

Budaya.

https://doi.org/10.17510/paradigma.v $8 \mathrm{i} 1.231$

Gorter, D. (2006). Minorities and Language. In Encyclopedia of Language \& Linguistics. https://doi.org/10.1016/B0-08044854-2/01295-5

Heyd, T. (2014). Folk-linguistic landscapes: The visual semiotics of digital enregisterment. Language in Society, 43(5), 489-514. https://doi.org/10.1017/S0047404514 000530

Kasanga, L. A. (2012). Mapping the linguistic landscape of a commercial neighbourhood in Central Phnom Penh. Journal of Multilingual and Multicultural Development, 33(6), 553-567.

https://doi.org/10.1080/01434632.201 2.683529

Koschade, A. (2016). Willkommen in Hahndorf: A Linguistic Landscape of Hahndorf, South Australia. International Journal of Humanities and Cultural Studies, 3(1), 692-716.

Kostanski, L. (2009). What's in a Name?': Place and Toponymic Attachment, Identity and Dependence: A Case Study of The Grampians (Gariwerd) National Park name restoration process. University of Ballarat.

Kreslins, J. (2003). Linguistic Landscape in the Baltic, Scandinavian Journal of History, 28(3-4), 165-174. https://doi.org/10.1080/03468750310 003659

Kusik, V. (2018). Onomastical analysis of inscriptions from Koper and its vicinty. Studia Universitatis Hereditati, Znanstvena Revija Za Raziskave in Teorijo Kulturne Dediščine.

https://doi.org/10.26493/23505443.3(2)69-98

Kusumaningsih, D., Sudiatmi, T., \& Muryati, S. (2013). Pengidonesiaan Kata dan Ungkapan Asing pada Nama Badan Usaha, Kawasan, dan Gedung 
[The Reservation of Foreign Words and Expressions on The Names of Business, Locations, and Buildings]. Jurnal Pendidikan.

Landry, R., \& Bourhis, R. Y. (1997). Linguistic landscape and ethnolinguistic vitality: An empirical study. Journal of Language and Social Psychology. 16(1), 23-49. https://doi.org/10.1177/0261927X970 161002

Lay, R. E. (2015). Linguistic Landscape of Main Streets in Bosnia and Herzegovina. Undergraduate Honors Theses. 302. https://dc.etsu.edu/honors/302 http://dc.etsu.edu/honors.

Lestari, S. (2013). Kajian Ragam Bahasa Slogan Pada Papan Reklame Di Kota Medan (Kajian Sosiolinguistik). Basastra, 2(2).

Lou, J. J. (2016). Jan Blommaert, Ethnography, superdiversity and linguistic landscapes: Chronicles of complexity. Bristol: Multilingual Matters, 2013. Pp. xiv, 127. Pb. $£ 17.95$. Language in Society. https://doi.org/10.1017/s0047404516 $00035 \mathrm{x}$

Madson, M. (2016). Rani Rubdy \& Selim Ben Said, Conflict, exclusion and dissent in the linguistic landscape. New York: Palgrave Macmillan, 2015. Pp. xvi, 306. Hb \$95.00. Language in Society.

https://doi.org/10.1017/s0047404516 000774

Manan, S. A., David, M. K., Dumanig, F. P., \& Naqeebullah, K. (2015). Politics, economics and identity: mapping the linguistic landscape of Kuala Lumpur, Malaysia. International Journal of Multilingualism, 12(1), 31-50. https://doi.org/10.1080/14790718.201 4.905581

Mooney, A. and B. E. (2018). Language, Society and Power: An Introduction. New York: Routledge.

Nash, J. (2016). Is linguistic landscape necessary? Landscape Researchch,
41(3),

380-384.

https://doi.org/0.1080/01426397.2016 .1152356

Pusat Bahasa Kemdikbud. (2016). Kamus Besar Bahasa Indonesia ( KBBI ). Kementerian Pendidikan Dan Budaya. Puzey, G. (2016). Linguistic Landscapes. In C. Hough (Ed.), The Oxford of Handbook of Names and Naming (pp. 476-496). Oxford: Oxford University Press.

Rahyono, F. . (2015). Kearifan Budaya dalam Kata. Edisi ke-2. Jakarta: Wedatama Widya Sastra.

Riani. (2014). Dominasi Bahasa Inggris pada Nama Badan Usaha di Yogyakarta [English Domination on Business Names in Yogyakarta]. Widyaparwa, 42(2), 141-152.

Richards., C. K. O. and I. A. (1923). The Meaning of Meaning. 8th. New York: Harcourt, Brace \& World.

Scollon, Ron, \& Scollon, W. S. (2003). Discourse in Place. Language in the Matherial World. Abingdon: Routledge.

Shohamy, E., \& Gorter, D. (2009). Linguistic Landscape: Expanding the Scenery. New York dan Loncon: Routledge.

https://doi.org/10.4324/97802039309 60

Shohamy, E., Ben-Rafael, L., \& Barni, M. (2010). Linguistic Landscape in the City. Bristol: Multilingual Matters.

Spolsky, B. (2004). The Nature of Language Policy and it's Domains. Language Policy. Cambridge University Press.

Stroud, C., A., \& Mpendukana., S. (2009). Towards a Material ethnography of Linguistic Landscape: Multilingualism, Mobility and Space in a South-African Township. Journal of Sociolinguistics, 13(3), 363-383.

Tang, H. K. (2016). Linguistic Landscaping in Singapore: The Local Linguistic Ecology and the Roles of English. Lund University Libraries. http://lup.lub.lu.se/student- 
papers/record/8878970..

Taylor-Leech, K. J. (2012). Language choice as an index of identity: Linguistic landscape in Dili, TimorLeste. International Journal of Multilingualism, 9(1), 15-35. https://doi.org/10.1080/14790718.201 1.583654

Wahyuni, S. (2016). Representasi Kekuasaan dalam Imbauan di Ruang Publik. Widyaparwa, 44(1), 41-50.

Wang, J.-J. (2015). Linguistic Landscape on Campus in Japan - A Case Study of Signs in Kyushu University. Intercultural Communication Studies XXIV, 24(1), 123-144.
Warung, Y. E. (2009). Menjaga integritas bahasa Indonesia di ruang publik. Menjaga Integritas Bahasa Indonesia di Ruang Publik.

Wijana, I. D. P. (2014). Bahasa, Kekuasaan, dan Resistansinya: Studi Tentang Nama-Nama Badan Usaha di Daerah Istimewa Yogyakarta. Humaniora, 26(1), 56-64.

Wolf, H.-G., Hans-Georg Wolf Zweitgutachter, H., Bernhard Bielick, H., \& Magdalena, A. (2012). English in the Linguistic Landscape of Hong Kong: A Case Study of Shop Signs and Linguistic Competence. Universität Potsdam. 